\title{
Recent Records of Exotic Reptiles on Pohnpei, Eastern Caroline Islands, Micronesia ${ }^{1}$
}

\author{
Donald W. Buden, ${ }^{2,3}$ D. Brian Lynch, ${ }^{2}$ and George R. Zug ${ }^{4}$
}

\begin{abstract}
Seven nonindigenous species of reptiles (two freshwater turtles, one gekkonid lizard, and four snakes) were recorded on Pohnpei and adjacent Ant Atoll (Federated States of Micronesia) for the first time within the past $15 \mathrm{yr}$, three within the past $3 \mathrm{yr}$. They apparently reached Pohnpei by deliberate or inadvertent human-assisted transport, originating from widespread and distant areas including North America, Southeast Asia, Indoaustralia, and other Pacific islands. Pohnpeians (and many other Pacific islanders) often do not perceive exotics as a potential threat to the balance of natural ecosystems. Additional training and education addressing the potentially disastrous consequences of alien species and directed especially toward agencies entrusted with monitoring environmental quality are recommended to help preserve biodiversity on these small island nations.
\end{abstract}

PohnPEI is a ruggedly mountainous (nearly $800 \mathrm{~m}$ high), densely forested, sparsely populated (31,540 people censused in 1994 [Office of Planning and Statistics 1996]) volcanic island in the west-central Pacific (Figure 1). It is located $766 \mathrm{~km}$ north of the equator. As the political and economic hub of the Federated States of Micronesia, Pohnpei hosts a broad spectrum of international visitors for business and recreation, despite its relatively small size (about $355 \mathrm{~km}^{2}$ ) and remote location. In addition, yachts in transit from different parts of the world frequently anchor at Pohnpei and its satellite atolls for indefinite periods of time. The potential for deliberate and inadvertent transport of exotic flora and fauna increases with the growing accessibility and popularity of the island. $\mathrm{Re}-$ cent human-assisted transport and establish-

\footnotetext{
${ }^{1}$ Manuscript accepted 30 January 2000.

2 Division of Natural Science and Mathematics, College of Micronesia, P.O. Box 159, Kolonia, Pohnpei, Federated States of Micronesia 96941. fm).

${ }^{3}$ Author for contact (E-mail: don_buden@comfsm.

${ }^{4}$ Department of Vertebrate Zoology, National Museum of Natural History, Smithsonian Institution, Washington, D.C. 20560.
}

Pacific Science (2001), vol. 55, no. 1:65-70

(C) 2001 by University of Hawai'i Press

All rights reserved ment of exotic species of plants and animals throughout the Pacific Basin are well recognized (McCoid 1993 from Drake et al. 1989). Guam and the Hawaiian Islands are notorious examples (Eldredge 1988, McCoid 1993, 1995, Fritts and Rodda 1998, Wiles in press) of the disastrous consequences of exotic flora and fauna. This study reports on the probable human-assisted occurrence of seven species of reptiles on Pohnpei and adjacent Ant Atoll recorded for the first time during the past $15 \mathrm{yr}$, three of them within the last $3 \mathrm{yr}$.

\section{SPECIES ACCOUNTS}

\section{Ocadia sinensis}

An adult female Chinese stripe-necked turtle (169 $\mathrm{mm}$ carapace length [CL]) was collected in a rain-filled rut or puddle near the power plant at Nipaip, about $3.0 \mathrm{~km}$ SSW of Kolonia on 16 July 1999. It was found by a local college student and given to a representative of the Fisheries Section of the Department of Economic Affairs; they in turn passed it to biologists at the College of Micronesia, and it is now deposited in the Smithsonian collections (USNM 529967). C. H. Ernst confirmed our identification. Ocadia sinensis is indigenous to Taiwan, southern China, and northern Vietnam (Ernst and Barbour 1989). The Pohnpei specimen is the first record for a west-central Pacific island. It may have been 


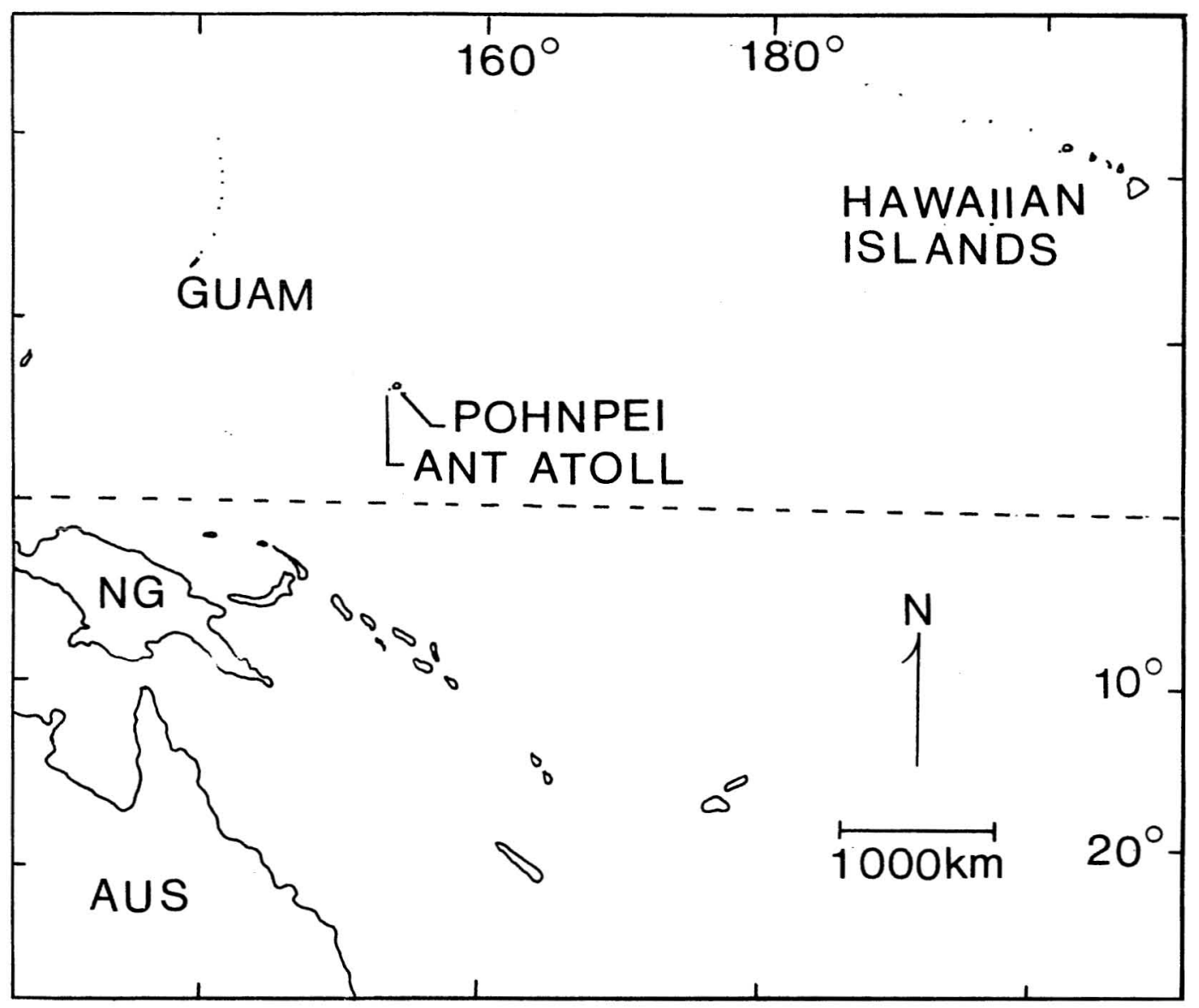

Figure 1. Location map for Pohnpei and Ant Atoll. AUS, Australia; NG, New Guinea; broken line indicates the equator.

transported by Asian visitors possibly via international flight or aboard one of the numerous foreign fishing vessels as a "pet" or as alternative food. Although $O$. sinensis is reported as being herbivorous (Ernst and Barbour 1989), a recent study of its food habits (Chen and Lue 1999:467) revealed it to be "an opportunistic omnivore with both plant and animal matter contributing substantially to the diet" in nature as well as in captivity. The Pohnpei specimen readily consumed small (approximately 20-40 mm standard length) gobiid fishes, as well as hawk moths (Sphingidae) and scincid lizards (Emoia jakati) during its brief period of captivity at the college.

\section{Trachemys scripta elegans}

A female red-eared turtle (170 mm CL) was captured at the public dump at Tekehtik near the Pohnpei airport on 20 January 1997 (Buden in press). It was examined by D.W.B. before being adopted as a "pet" by a government worker. Letters to several government offices pointing out the environmental problems often caused by exotic species and recommending that the turtle be preserved as a voucher specimen were officially approved and condoned during passage through subsidiary offices, but the turtle remains in captivity $2 \mathrm{yr}$ after capture. This species is indigenous to the southeastern and central 
United States (Ernst 1990), but dispersal via the pet trade has resulted in numerous disjunct populations worldwide (Luiselli et al. 1997). In the Pacific, it has been recorded in Hawai'i (McKeown 1978), Guam (McCoid 1992, 1993), and Saipan (McCoid 1992). D.W.B. interviewed a local resident who claimed the turtle very much resembled one that he purchased in a pet store in California (U.S.A.) and brought to Pohnpei in 1983 or 1984, when it was "3-4 inches long"; it was lost or stolen 2 or $3 \mathrm{yr}$ later. Whether it is the same turtle recently recovered at the Tekehtik dump is uncertain.

\section{Hemidactylus frenatus}

The house gecko was recorded on Pohnpei first by Petren et al. (1993), but unspecified as to date. The earliest documented record we found was a specimen in the California Academy of Sciences (cas 160111) collected by J. Vindum and S. Turpie near the Village Hotel (about $6 \mathrm{~km}$ east of Kolonia) on 17 February 1986 (Buden in press). Hemidactylus frenatus is now the most abundant gecko in Kolonia, occurring also in densely settled areas elsewhere on the island. It was common at the Pohnpei Agriculture and Trade School (PATS) on the side of the island opposite Kolonia during a herpetological field survey in summer 1995, but was uncommon on adjacent Temwen Island, which is separated from the main island by a causeway about $250 \mathrm{~m}$ long. Native to Asia and the IndoPacific, the house gecko has been spreading rapidly throughout the Pacific Basin islands assisted by human transport (Case et al. 1994); the specific provenance of the Pohnpei population is uncertain.

\section{Unidentified typhlopid}

A blindsnake (USNM not yet cataloged) was collected on Ant Atoll about $18.5 \mathrm{~km}$ southwest of Pohnpei during summer 1999. It does not appear to be the brahminy blindsnake, but its specific identity is still unconfirmed. Details of its capture and a discussion of its possible dispersal will be given elsewhere (R. P. Reynolds, A. Wynn, and D.W.B., unpubl. data).

\section{Boiga irregularis}

The first documented record of a brown tree snake from the Federated States of Micronesia is a specimen (USNM 339786) that was found dead on a cargo container in a ship from Guam at Kolonia Harbor on 3 November 1994 (Buden in press).

\section{Dendrelaphis sp.}

Buden (in press) reported a snake that was found alive at the Kolonia Elementary School grounds during the late 1980 s, preserved in formalin, identified as a member of the genus Dendrelaphis by T. Fritts, kept at the College of Micronesia for several years, and subsequently donated to the Smithsonian collections (USNM 506906). Fritts (in Jaffe 1994) speculated that it may have been brought to the island from Palau, the nearest island where "bronze-backs" are known, possibly as a joke by one of the Palauan students at the Kolonia campus of the College of Micronesia. That origin is a possibility; however, the identity remains uncertain. The uncertainty arises from the poor condition of the specimen and also from the uncertain systematics of Pacific-area Dendrelaphis. Exotic Dendrelaphis are often quickly labeled as either $D$. calligaster or D. pictus; this specimen is neither of those two species.

\section{Lycodon aulicus}

A wolf snake was collected at Pohnpei in a shipment of lumber from the Philippines (via Guam) in August or September 1986 (Fritts 1987). Another (USNM 28246) is cataloged as collected on Pohnpei by Dr. Bartels around 1900 , but the provenance of many of Bartels' specimens is questionable (R. I. Crombie, unpubl. notes in Buden in press).

\section{DISCUSSION}

Buden (in press) recorded 18 species of terrestrial reptiles resident on Pohnpei, including 17 lizards (Varanidae, 1; Gekkonidae, 7; Scincidae, 9) and one blindsnake (Rampbotypblops braminus). The monitor lizard (Varanus indicus) was deliberately introduced in the 
early 1900s, during the Japanese administration, and the brahminy blindsnake doubtless is another old but probable accidental introduction of unknown origin. The sources, chronology, and modes of dispersal of most of the reptile species on Pohnpei are uncertain. Crombie and Steadman (1987) suggested that nearly all lizards on remote Pacific islands may have arrived by deliberate or inadvertent human activity, and Eldredge (1988) held to a similar opinion specifically in reference to the terrestrial vertebrate fauna of Micronesia and American Samoa. On the other hand, recent studies of genetic variation in populations of lizards from Oceania indicate natural dispersal may be more prevalent than previously thought (Fisher 1997).

Anthropochory almost certainly accounts for all seven of the most recently recorded nonindigenous land reptiles on Pohnpei. Two of the snakes (Boiga and Lycodon) are known to have been transported via cargo ship, and one of the turtles (Trachemys) was brought to the islands as a pet, hand carried on a commercial airliner. Six of the seven species belong to large taxonomic assemblages (i.e., freshwater turtles and land snakes) that are not part of the resident herpetofauna (excluding the earlier introduction of $R$. braminus). Their underrepresentation on oceanic islands, even where suitable habitats seem to be present, suggests poor natural dispersal across extensive saltwater barriers. The seven recently recorded species derive from numerous disparate sources worldwide, including Indoaustralia (unidentified typhlopid, Dendrelaphis), southern China or Taiwan (Ocadia sinensis), the United States (Trachemys), Guam (Boiga), the Philippines (Lycodon), and any one or a combination of different Pacific Basin area sources in the case of Hemidactylus frenatus, with Guam and $\mathrm{Ha}-$ wai' $i$ being the most likely in view of the high volume of "contact" with Pohnpei. Only Hemidactylus frenatus of the seven reported exotics is established on Pohnpei or its outliers; each of the others is known from a single isolated occurrence, with the possible exception of one additional but somewhat questionable century-old record of Lycodon aulicus. With the exception of the unidentified typhlopid (but see Reynolds et al., unpubl. data), all were found in areas of human habitation and mainly in the vicinity of Kolonia, the port of entry.

We believe that the disposition of these specimens of exotic species for the most part was handled appropriately. But inaction in the case of Trachemys scripta, apparently brought to Pohnpei without authorization and kept in private possession contrary to specific official recommendation and statutes regarding the importation of plants and animals, is cause for concern. The threat of environmental damage caused by alien species is well recognized, especially on islands, which lack the more extensive buffer zones of continental landmasses. Soulé (in Jaffe 1994:167) has predicted that "the intercontinental traffic of exotic organisms, including their associated pathogens, will grow with the increasing mobility of people and commodities," and Coblentz (in Jaffe 1994:168) stated, "most exotics, once they become established are usually permanent in ecological time. In a few instances, exotic organisms may be eradicated or controlled, usually at great expense and after severe environmental disturbance has already occurred, but most are uncontrollable and in comparison with human life span are in place in perpetuity." The representatives of local governments and conservation agencies charged with protection of the natural resources, especially of small island nations, need to be well informed of the possible threat of exotics to natural ecosystems and to take decisive action to prevent the possible introduction and establishment of potentially damaging alien species. To achieve this end, training and education may need to be intensified because many islanders are unaware of the potentially devastating effects of exotics. To the contrary, introductions are often perceived as a good thing, adding color and variety to somewhat impoverished (albeit often unique) biota. In addition, the transport of plants and animals among different island communities is part of local tradition and culture-sharing resources with friends and family and, at least in his- 
torical times, ensuring survival by establishing primary and supplemental food resources.

\section{ACKNOWLEDGMENTS}

We thank Francis Itimai, head of Fisheries Section, Department of Economic Affairs, National Government, for contributing the specimen of Ocadia sinensis and Carl H. Ernst for confirming its identification. Staff from Phoenix Marine Sports Club and Konrad Englberger, Plant Protection Training Officer, contributed the unidentified typhlopid. We also thank Jens Vindum for providing data on herpetological specimens from Pohnpei in the California Academy of Sciences, including the earliest known record of Hemidactylus frenatus. Bill Raynor (The Nature Conservancy, Pohnpei) kindly measured the Trachemys scripta for us.

\section{Literature Cited}

Buden, D. W. in press. The reptiles of Pohnpei, Federated States of Micronesia. Micronesica.

Case, T. J., D. T. Bolger, and K. Petren. 1994. Invasions and competitive displacement among house geckos in the tropical Pacific. Ecology 75:464-477.

Chen, T. H., and K. Y. Lue. 1999. Food habits of the Chinese Stripe-necked Turtle, Ocadia sinensis, in the Keelung River, northern Taiwan. J. Herpetol. 33:463471.

Crombie, R. I., and D. W. Steadman. 1987. The lizards of Rarotonga and Mangaia, Cook Island Group, Oceania. Pac. Sci. 40:44-57.

Drake, J. A., H. A. Mooney, F. D. Castri, R. H. Groves, F. J. Kruger, M. Rejmanek, and M. Williamson, eds. 1989. Biological invasions: A global perspective. John Wiley and Sons, Chichester. 525 pp.

Eldredge, L. G. 1988. Case studies of the impacts of introduced animal species on renewable resources in the U.S.-affiliated Pacific Islands. Pages 26-46 in B. D. Smith, ed. Topic reviews on insular re- source development in the Pacific U.S.affiliated islands. Univ. Guam Mar. Lab. Tech. Rep. 88.

Ernst, C. H. 1990. Systematics, taxonomy, variation, and geographic distribution of the slider turtle. Pages 57-67 in J. W. Gibbons, ed. Life history and ecology of the Slider Turtle. Smithsonian Institution Press, Washington, D.C.

Ernst, C. H., and R. W. Barbour. 1989. Turtles of the world. Smithsonian Institution Press, Washington, D.C.

Fisher, R. N. 1997. Dispersal and evolution of the Pacific Basin gekkonid lizards $G e$ byra oceanica and Gebyra mutilata. Evolution 51:906-921.

Fritts, T. H. 1987. Movements of snakes via cargo in the Pacific region. 'Elepaio 47: 17-18.

Fritts, T. H., and G. H. Rodda. 1998. The role of introduced species in the degradation of island ecosystems: A case history of Guam. Annu. Rev. Ecol. Syst. 29:113-140.

Jaffe, M. 1994. And no birds sing. Simon and Schuster, New York.

Luiselli, L., M. Capula, D. Capizzi, E. Filippi, V. Trujillo Jesus, and C. Anabaldi. 1997. Problems for conservation of pond turtles (Emys orbicularis) in central Italy: Is the introduced red-eared turtle (Trachemys scripta) a serious threat? Chelonia Cons. Biol. 2:417-419.

McCoid, M. J. 1992. Geographic distribution: Trachemys scripta elegans. Herpetol. Rev. 23:26.

. 1993. The "new" herpetofauna of Guam, Mariana Islands. Herpetol. Rev. 24:16-17.

-1995. Non-native reptiles and amphibians. Pages 433-437 in E. T. LaRoe, G. S. Farris, C. E. Puckett, P. D. Doran, and M. J. Mae, eds. Our living resources. U.S. Department of the Interior, National Biological Service, Washington, D.C.

McKeown, S. 1978. Hawaiian reptiles and amphibians. Oriental Publ., Honolulu. 80 pp.

Office of Planning and Statistics. 1996. National detailed tables, 1994 FSM census of population and housing. Office of Plan- 
ning and Statistics, National Government, Federated States of Micronesia, Palikir, Pohnpei.

Petren, K., D. T. Bolger, and T. J. Case. 1993. Mechanisms in the competitive success of an invading sexual gecko over an asexual native. Science (Washington, D.C.) 259:354-358.

Wiles, G. J. in press. Recent records of reptiles and amphibians accidentally transported to Guam, Mariana Islands. Micronesica. 